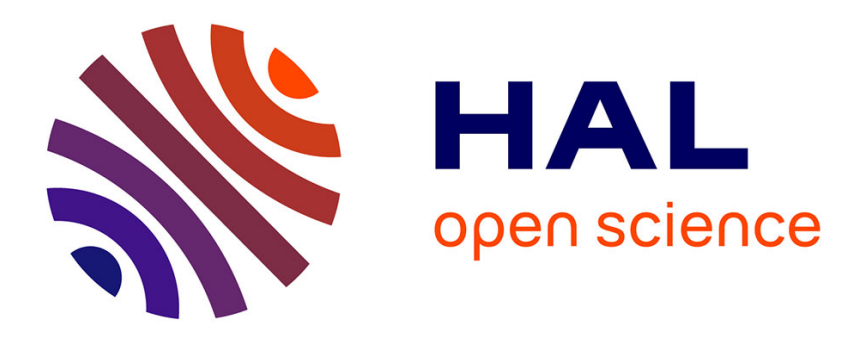

\title{
Sovereign Risk: A Reappraisal
}

Didier Maillard

\section{To cite this version:}

Didier Maillard. Sovereign Risk: A Reappraisal. 2020. hal-02989206

\section{HAL Id: hal-02989206 \\ https://hal.science/hal-02989206}

Preprint submitted on 3 Dec 2020

HAL is a multi-disciplinary open access archive for the deposit and dissemination of scientific research documents, whether they are published or not. The documents may come from teaching and research institutions in France or abroad, or from public or private research centers.
L'archive ouverte pluridisciplinaire HAL, est destinée au dépôt et à la diffusion de documents scientifiques de niveau recherche, publiés ou non, émanant des établissements d'enseignement et de recherche français ou étrangers, des laboratoires publics ou privés. 


\title{
Sovereign Risk: a Reappraisal
}

\author{
Didier MAILLARD $^{1}$
}

December 2013

${ }^{1}$ Professor, Conservatoire national des arts et metiers, Senior Advisor, Amundi 


\begin{abstract}
The Greek drama of the late 2000s has returned sovereign risk awareness to centre stage. The default affected a country with a relatively developed economy. It resulted in huge losses for the value of domestic assets: public debt, but also private debt, equity, real estate and furthermore pension rights and human capital. The burden has, not entirely but importantly, fallen on residents.

The questions that arise from the possibility of sovereign default impacting the sovereign's subjects are how to properly assess the risk, what the fallout from its occurrence would be and what precautionary measures should be taken. International diversification is part of the answer.
\end{abstract}

JEL classification: E62, G11, H2, H6

Key Words: Sovereign risk, public finance, public debt, solvency, restructuration, taxation, sustainability, risk assessment, asset allocation 


\section{1 - Introduction ${ }^{2}$}

The Greek drama of the late 2000s has returned sovereign risk awareness to centre stage. Not because there has never been a sovereign default before: they have been occurring for centuries, if not millennia, and Greece has experienced at least a dozen in the last two centuries. But now, with the "Great Moderation", we have been in a period of calm since the end of the 1990s. Admittedly, Greece was an old sinner but it is now part of the European Union and, for better or worse, part of the eurozone: a European democracy that is not rich but actually not poor, and is a member of an exclusive club.

There once was a time when savings were concentrated in developed economies and where promising investment opportunities were found in less developed economies. These potential investments were exposed to the risk of sovereign default in the region where they were made: the risk was direct in the case of sovereign funding and indirect in the case of mines, railroads, canals, etc. Although its potential importance was often neglected, sovereign risk was nonetheless viewed as a reality. But, in the minds of savers, sovereign risk was mainly a problem for foreign assets.

Greece, as a developed county, has been faced with the default of its own sovereign. This is a relatively new scenario, which may be relevant to other countries. The questions it raises are how to assess the risk, what the fallout from its occurrence would be and what precautionary measures should be taken.

\section{2 - What is sovereign default?}

Default occurs when a borrower does not settle a debt that it undertook to pay in full on a specified due date. Whether the borrower withholds payment, repudiates its debt or unilaterally transforms the nature of the debt obligation (through renegotiation or not), it is considered default. This definition applies to sovereign borrowers and other types of debtors alike. However, there is a difference between a sovereign borrower and other debtors: the sovereign frequently controls the currency in which its debt is denominated.

\footnotetext{
${ }^{2}$ A version of this paper has been published in Commentaire ${ }^{\circ}{ }^{144}$, Winter 2013-2014
} 
When the debt obligation is denominated in the national currency and is not indexed (whether to inflation, gold, a basket of commodities or a foreign currency), the sovereign borrower is usually able to print enough money to service its debt on time. The central bank's charter of independence does not count for much in the event of a crisis: the President of the United States could always persuade the Federal Reserve, using an armoured division if necessary, to provide the dollars needed to make payment on a bond or a Treasury note. Even so, there could be a problem when the sovereign is divided (the President at odds with the United States Congress) or if the sovereign undergoes a transformation, especially a sudden one following a revolution.

However, the use of the printing press to repay debts entails the risk of inflation. The purchasing power of the repaid debt will be lower than the creditor took for granted and will impoverish it in the same manner as failure to repay or partial repayment in the event of default. It may not be a default in the legal sense of the word, but the economic fallout would be the same. "Default by stealth" is something that occurs frequently: France itself used it in the aftermath of both world wars, in particular WWII.

When a debt obligation is denominated in a foreign currency or indexed to elements beyond the sovereign's control, it is impossible to alter the face value. In this case, you would expect to see default occur more frequently ${ }^{3}$. But - and this point should be stressed - the debt obligations of eurozone sovereigns are now entirely represented by debt denominated in a foreign currency: no country can force the European Central Bank to provide the money necessary to repay its debt. Perhaps a coalition of countries could but putting together such a coalition would be hard. Furthermore, one of the purposes of the European monetary union was to limit the powers of sovereigns over money.

Finally, unlike other debtors, sovereigns have another means at their disposal to avoid default: imposing a tax on their debt or on debt interest payments. Implementation of this tax is more tricky but not impossible when foreigners hold the debt. For savers in the sovereign's own territory, a range of "financial repression" measures can be used to sharply restrict or encourage the purchase of national debt (Drut, 2013).

\footnotetext{
${ }^{3}$ In addition, altering the face value is considered to be more difficult when the law regulating the debt obligation is not that of the sovereign and is issued by a foreign jurisdiction.
} 


\section{3 - The fallout from default by a sovereign borrower}

The first consequence from default by a sovereign borrower is the recognition of an impairment loss on its debt: public debt. The loss can be total but, more often than not, it is partial. It can take the form of a reduction in face value, lower interest rates or extended maturities at the same or a reduced interest rate. In any event, an actuarial impairment loss is recognised. The loss can vary based on the securities comprising the debt, which make an overall assessment all the more difficult. Recent experience, including that of Greece, suggests a standard along the lines of $50 \%$ for any haircut imposed on holders of sovereign debt.

An impairment loss on public debt spills over into debt issued by corporations and institutions falling within the defaulting sovereign's jurisdiction. It also spills over into the equity market via a number of channels. Corporations can expect to suffer a loss of business and profits due to a decline or even collapse of the gross domestic product accompanying a default. They will also presumably be hurt by taxes and levies imposed by the sovereign in an attempt to improve its own situation. Corporations with a significant percentage of their assets in foreign countries will of course suffer less than those operating only in the domestic market.

In the case of Greece, the impairment loss on equities listed the general index of the Athens Stock Exchange exceeded 80\% after the high recorded in December 2007.

Economic difficulties and a heavier tax burden can also have an impact on the housing market, leading to lower prices on what constitutes a major element of household wealth. In Greece, the price of previously-owned homes fell 30\% between 2008 and mid-2013 (Source: Bank of Greece).

Overall the price of domestic real and financial assets can be expected to undergo deep declines. But it doesn't end there: retirement pensions distributed or guaranteed by the sovereign will undergo substantial cuts, bringing about a reduction of any benefits to which current and future retirees are entitled; and, amid higher unemployment and lower wages, human capital will also be devalued. 
The sovereign's subjects will experience a consequent deterioration of wealth in all sectors across all domestic assets, following the sovereign's default.

\section{4 - Assessing the risk}

Assessing the risk of default by a sovereign borrower is a tricky business and the subject of sizeable literature. First and foremost, of course, risk depends on the size of public debt. This leads to the question of whether there exists a threshold for debt ${ }^{4}$, below which risk is likely to be insignificant and above which it would be palpable. However, other factors are involved: the size of the sovereign's off-balance sheet liabilities, in particular retirement benefits; the tax burden level already reached, its concentration or dilution; and, finally, the dynamism of the economy, which provides the tax base.

The risk of default by a sovereign borrower therefore depends on the amount of its debt. Expressed in monetary units, the amount of debt doesn't mean too much. This is why it is standard practice to compare the value of debt to the size of economies. For households and corporations alike, income is frequently measured to assess the debt burden and establish limits. Some hold the view that household debt (in most instances contracted due to a home purchase) should not exceed three or four years of income. For corporations, debt is measured against earnings or cash flow.

For the sovereign, debt is most often measured against GDP and debt-to-GDP ratios are familiar to everyone. GDP corrects monetary and economy-size factors for the purpose of assessment and comparison of sovereign debts throughout time and space. Today, a number of developed countries are hovering around or exceeding a public debt to GDP ratio of $100 \%$. This has been a growing trend for thirty or more years, without these countries having experienced any particular catastrophe, such as a war on their national territory ${ }^{5}$. Under these circumstances, exogenous factors do not properly account for the high ratio and the levels reached are historically unprecedented in certain respects. Several countries have experienced

\footnotetext{
${ }^{4}$ A threshold of $90 \%$ for the debt-to-GDP ratio suggested by Reinhart and Rogoff and which has been the subject of lively debate and methodological criticisms concerns the impact on GDP growth. As GDP determines the dynamics of the taxable base, it naturally influences a crucial aspect of the sovereign's solvency.

${ }^{5}$ An exception to this observation is perhaps Germany, which had to absorb the shock of reunification.
} 
a public expenditure bubble owing to the accumulation of layers of clientelist spending in universal suffrage democracies (Bastiat, 1862, Olson, 1965).

Alongside debt there exists sizeable implicit debt: the commitments of retirement schemes that do not rely on real and financial assets but on the sovereign's power to tax. This is true not only of civil servants' pensions when they are paid directly out of the sovereign's pocket but also of pay-as-you-go schemes that rely on the sovereign's delegation of its power to tax by making contributions to such schemes compulsory. Such benefits, which are quite considerable in France and in other European countries, are equivalent to public debt. But even if this were not so, they restrict the sovereign's power to tax in order to tackle is own debt.

The question of the seniority of the two types of debt is not an obvious one. At first glance, it's easier for the sovereign to reduce its retirement obligations by slightly adjusting the eligibility and valuation rules, thereby implementing a sort of default by stealth. But if the sovereign takes the form of an elected government, it would find itself at odds with a substantial portion of the electorate.

GDP is roughly equivalent to income ${ }^{6}$. But it is national income, that is, the income of the governed and not of the sovereign. The sovereign can levy only a share of national income and the size of national income is not unrelated to the percentage the sovereign seeks to obtain.

There are economic limits on the amount of tribute a sovereign can exact from its territory (Dupuit, 1844, Laffer,1978). There are political limits, too, often referred to as "consent to taxation".

In France, the tax burden is very heavy - one of the heaviest in the world - and it is increasingly concentrated on a minority. Perhaps we are not far from entering "law of the vital few" territory: $20 \%$ of the working and investing population is the source of $60 \%$ of all wealth

\footnotetext{
${ }^{6}$ Not exactly, as GDP is gross of capital consumption, which is basically a loss of wealth during the period; in addition, GDP includes a conventional measure of production by government (so called non-marketable GDP), assessed as its producing cost, which exists only because of the taxes levied on the private sector. GDP therefore overstates the real (taxable) national income.
} 
creation and pays $80 \%$ of all taxes ${ }^{7}$. On the other hand, expenditure is increasingly concentrated on categories that are not paying the taxes: increased means testing for government benefits and subsidies.

Historically, sovereigns have exacted tribute first from conquered peoples and then from its own subjects. In exchange, sovereigns provided a few services to their subjects, the most important being protection of their person and property. Today sovereigns have a hand in multiple actions and a widening gap is forming between taxpayers and beneficiaries, which is likely to undermine the tax base.

A sovereign's balance sheet is relatively straightforward. The bulk of its assets is made up of the present value of future taxes that it could impose (hence the importance of the dynamic growth of the tax base and, therefore, the economy). The sovereign state has very few productive assets and it is often estimated that it receives lower returns than a private property owner leading to privatisation pressure on sovereigns in trouble. It is the present value of future taxes that is the guarantee that the debt and other liabilities will be honoured. A sovereign's capacity to tax a sustainable portion of a dynamic base is therefore crucial.

\section{5 - What to do in the face of sovereign risk?}

Firstly, one can think of frameworks destined to restrict the sovereign's actions and impose norms on it designed to avoid a possible default. These standards can be international commitments, in particular European, or enforceable legal or constitutional domestic standards. The problem is that the sovereign is only too happy to fight back as it regards itself as a sovereign. The budgetary constraints arising from the Maastricht Treaty and the Stability Pact have been cheerfully ignored. The French law creating a "tax shield" designed to avoid an excessive rate of taxation and to preserve the tax base, has been suppressed. Prescriptive safeguards are therefore often not effective instruments to avoid a default.

As we have seen, a default by your own sovereign country seriously affects the value of all "domestic" assets: public debt, bonds, equities, homes, retirement benefits and human capital.

\footnotetext{
${ }^{7}$ The tax burden on capital in France is especially heavy (Maillard, 2013).
} 
This could cast international diversification of investments in a different light, in particular investments to provide income for retirement.

International diversification of investments is a relatively rare practice: on the whole, residents own most domestic real estate, the lion's share of the country's public debt and listed shares and most unlisted shares. Even where there is little risk of a sovereign default, the small scale of diversification is hard to justify: for a same level of risk ${ }^{8}$, a more diversified portfolio can be expected to provide a better chance of return, unless yields from foreign assets take a hit due to high transaction or information costs or to differences in tax treatment playing in the favour of domestic assets. Such costs on their own do not account for the domestic bias we observe.

If sovereign risk does indeed exist, international diversification becomes all the more attractive. Sovereign defaults are far from being perfectly correlated so it is possible to mitigate the effects of sovereign risk by diversifying the sovereigns. The advisability of international diversification is all the greater when retirement benefits guaranteed by the sovereign and human capital linked to residency are substantial. It should be stressed that human capital can be subject to ex ante (international career opportunities) or ex post diversification, under less advantageous conditions: migration to other countries by workers from countries that have experienced default or where the probability of default is substantial, often with the necessity of taking less skilled jobs.

The thinking we've outlined here merits further exploration, taking into account the situation and characteristics of the sovereign's subjects. It could lead to a revision of approaches to asset allocation and portfolio optimisation.

\footnotetext{
${ }^{8}$ Foreign assets can be intrinsically more risky, which limits their usefulness when investors are building a diversified portfolio, because of foreign exchange risk. But this risk can be reasonably hedged in the short term. Over the long term, the general thinking is that the foreign exchange risk disappears all the sooner if the portfolio is diversified across several currencies.
} 


\section{References}

Canto V.A., D.H. Joines and Arthur D. Laffer, 1978, “Taxation, GNP and potential GNP”, Proceedings of the business and economic statistic section in San Diego, American statistical association, p. 122-130

Bastiat Frédéric, 1862-64, “Oeuvres completes (Complete works), ed. Giraudin

Drut Bastien, 2013, "Répression financière: une tentation pour "liquider" la dette publique (Financial repression: the temptation to eliminate public debt), Revue Française d'Économie, $\mathrm{N}^{\circ}$ XXVII, 3, January 2013

Dupuit Jules 1844, "De la mesure de l'utilité des travaux publics" (On the measure of the utility of public works), republished in Revue française d'économie, $\mathrm{n}^{\circ} 10-2,1995$, pp. 55-94

Maillard Didier, 2013, « The Unbearable Heaviness of Capital Taxation in France”, Working Papers Series, SSRN, December 2013

Maillard Didier, 2011, «Where's the Value of Wealth Management: Tax Planning or Asset Management? », Working Papers Series, SSRN n¹955868, September 2011

Olson, Mancur, 1965, “The Logic of Collective Action”, Harvard University Press

Reinhart Carmen and Kenneth Rogoff and, 2009, This Time is Different: Eight Centuries of Financial Folly, Princeton University Press. 